\title{
Reading in developmental dyslexia: the role of phonemic awareness and executive functions
}

\author{
Leitura na dislexia do desenvolvimento: o papel da \\ consciência fonêmica e das funções executivas
}

\author{
Giovanna Beatriz Kalva MEDINA 1 iD 0000-0003-4464-9701 \\ Sandra Regina Kirchner GUIMARÃES ${ }^{2}$ ID 0000-0003-3441-0983
}

\begin{abstract}
This study investigated the correlations and the possible deficits in reading, phonemic awareness, and executive functions among students with developmental dyslexia. A total of 28 students participated in the study, between 9 and 11 years old, 14 with developmental dyslexia and 14 without reading difficulties. Specific instruments were used to assess reading, phonemic awareness, and executive functions. The Spearman test indicated moderate and very significant correlations between performance in tasks of phonemic awareness and reading (recognition and comprehension) and tasks that assessed cognitive functioning involving the following executive functions: cognitive flexibility, working memory, inhibitory control, and orthographic verbal fluency. No correlation was found between the reading and phonemic awareness assessments and the results of the planning done with the Tower of London instrument. The results allowed the researchers to hypothesize that an intervention planned for the development of phonemic awareness and executive functions may have an effect in improving the reading performance of dyslexics.
\end{abstract}

Keywords: Awareness; Dyslexia, Developmental; Executive function; Reading.

\section{Resumo}

Este estudo investigou as correlações e os possiveis déficits em leitura, consciência fonêmica e funções executivas entre estudantes com dislexia do desenvolvimento. Participaram do estudo 28 estudantes, com idade entre 9 e 11 anos, sendo $14 \mathrm{com}$ dislexia do desenvolvimento e 14 sem dificuldade de leitura. Foram utilizados instrumentos específicos para

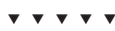

1 Centro Universitário FAE, Curso de Psicologia, Departamento de Psicologia. R. 24 de Maio, 135, Centro, 80230-080, Curitiba, PR, Brasil. Correspondence to G.B.K. MEDINA. E-mail: <giovannabkmedina@gmail.com>.

2 Universidade Federal do Paraná, Setor de Educação, Programa de Pós-Graduação em Educação. Curitiba, PR, Brasil. Article based on the dissertation of G.B.K. MEDINA, entitled "Aperfeiçoamento da leitura em estudantes com dislexia do desenvolvimento com o método fônico associado à estimulação das funções executivas e estratégias metacognitivas”. Universidade Federal do Paraná, 2018.

How to cite this article

Medina, G. B. K., \& Guimarães, S. R. K. (2021). Reading in developmental dyslexia: the role of phonemic awareness and executive functions. Estudos de Psicologia (Campinas), 38, e180178. https://doi.org/10.1590/1982-0275202138e180178 
avaliação da leitura, consciência fonêmica e funções executivas. O teste Spearman indicou correlações moderadas e muito significativas entre o desempenho nas tarefas de consciência fonêmica e leitura (reconhecimento e compreensão) e as tarefas que avaliaram o funcionamento cognitivo envolvendo as seguintes funções executivas: flexibilidade cognitiva, memória de trabalho, controle inibitório e fluência verbal ortográfica. Não foi encontrada correlação entre as avaliações de leitura e consciência fonêmica e planejamento com o instrumento Torre de Londres. Os resultados possibilitam hipotetizar que uma intervenção para o desenvo/vimento da consciência fonêmica e das funções executivas pode melhorar o desempenho em leitura dos disléxicos.

Palavras-chave: Consciência; Dislexia do desenvolvimento; Funções executivas; Leitura.

Investigations to understand the cognitive functions involved in learning disorders have intensified in recent years, aiming mainly at the development of more effective forms of intervention (Snowling, 2004; Vellutino \& Fletcher, 2013). The reading learning disorder, also called dyslexia, is characterized as a persistent difficulty in decoding and reading isolated words aloud, writing words correctly, and understanding what was read (American Psychiatric Association, 2014), despite the intellectual potential, which must be within the expected average for the chronological age. Children with dyslexia: "typically have above average intelligence, with a significantly delayed development of their literary aptitude. In addition, reading and spelling strategies are often different from those observed in a child with normal development" (Snowling, 2004, p. 2).

Of neurobiological origin, developmental dyslexia results from deficiencies in phonological processing, especially in phonological awareness (Snowling \& Hulme, 2013), in the ability to perceive the structure of the word (Gough \& Larson, 1995); that is, they reveal that there is a deficit in the understanding that "spoken words consist of individual speech sounds (phonemes) or combinations of speech sounds (syllables and intrasyllabic units)" (Vellutino \& Fletcher, 2013, p. 382). For Snowling and Hulme (2013), the failure in the phonological system seems to be the most plausible cause for dyslexia; even with studies looking for other possible causes, the phonological deficit, which can vary in intensity, is responsible for most cases of developmental dyslexia, as the inadequate phonological coding interferes with reading acquisition.

Regardless of the reading pattern, Godoy (2016) found that phonological awareness is strongly correlated with the ability to spell and read in skilled readers, but it does not necessarily have a unidirectional causality relationship, as these abilities develop simultaneously. The ability to perceive and manipulate phonemes (segment and invert) at the beginning of literacy is strongly predictive of an efficient reading ability that will only be solidified years later.

To meet the cognitive demand related to reading, it is possible to highlight different cognitive resources that support its implementation, among themselves and for this article, more specifically basic and high executive functions. Working memory, inhibition, and cognitive flexibility are called basic executive functions that allow the development of high Executive Functions (EF), such as: problem solving, planning, monitoring, assessment, organization, self-awareness, creativity, self-control, among others (Corso, Sperb, Jou, \& Salles, 2013; Diamond, 2013, 2016; Lezak, 1982; Seabra, Laros, Macedo, \& Abreu, 2014). For Diamond (2013), high EF correspond to fluid intelligence, as they participate in the cognitive processing involved in the performance of everyday activities - the different experiences and work situations, activities in which the participant needs to reason in order to know what do. Even when it comes to an activity whose solution has not been mastered by the participant, high EF allow him to find a way out to perform it.

In reading, EF coordinate different stimuli through inhibitory control, decoding information and handling it through cognitive flexibility, retaining and manipulating the data phonologically and visually captured in their Working Memory (WM) (Cypel, 2016; Diamond, 2013; Medina, Guimarães, \& Minetto, 2017; Seabra et al., 2014).

The most studied executive function in learning difficulties is working memory (WM) (Reiter, Tucha, 2 \& Lange, 2005). Studies are aimed at understanding how the overall performance of WM is in students 
with reading disorders (Medina et al., 2017) and also at verifying the impact of interventions on executive functions, including WM, to improve reading skills (Medina \& Guimarães, 2019).

Numerous studies point to a deficit in phonemic/phonological awareness and executive functions in dyslexics; few, however, assess the correlation of performance in these two assessments. In the studied carried out by Cardoso, Silva, and Pereira (2013), there was a correlation between the results of working memory and the phonemes subtests of the Consciência Fonológica: Instrumento de Avaliação Sequencial (CONFIAS, Phonological Awareness: Sequential Assessment Tool) test in the two groups of participants. The researchers claim "that there is a dependency relationship between these two skills, since the nature of the information processed is phonological", and the working memory acts in "coding, storing, and retrieving the information necessary to perform phonological awareness tasks" (Cardoso et al., 2013, p. 113). On the other hand, Moura, Moreno, Pereira, and Simões (2015a), when they found a correlation between phonemic awareness and Short-Term Verbal Memory or phonological working memory, found that Short-Term Verbal Memory contributes little to the fluent reading of texts or words, when the other variables (phonemic awareness and rapid automatic naming) are controlled.

Berninger, Raskind, Richards, Abbott, and Stock (2008) report that deficits in WM can explain problems in decoding, spelling, and fluency in individuals with dyslexia. Sesma, Mahone, Levine, Eason, and Cutting (2009) identified that WM and planning contribute to understanding, with WM being responsible for retaining information in memory while extracting its meaning. In addition, studies have shown that, despite the improvement in reading abilities over the years, dyslexics continue to have difficulties in working memory until adulthood, which implies an executive dysfunction (Fostick \& Revah, 2018; Smith-Spark \& Fisk, 2007). This finding confirms the theory of multiple deficits in dyslexia, which overlaps the exclusively phonological deficit.

According to Bovo, Lima, Silva, and Ciasca (2016), Verbal Fluency (VF) contributes to the quick access of the mental lexicon, however, working memory (phonological and visuospatial), attention, and inhibitory control are important and indispensable instruments, so that the reading comprehension orchestra can perform a beautiful symphony. Moura, Simões, and Pereira (2013) and Smith-Spark, Henry, Messer, and Zięcik (2017) point out that VF assessment allows to capture data of various functions and complex cognitive processes, such as: initiative, cognitive flexibility, processing speed, abstraction and planning, working memory, sustained attention, recovery of words in the language mental lexicon and verbal aptitude. Due to the deficits found in dyslexics, VF assessment can be identified as a predictor of dyslexia (Horowitz-Kraus, Toro-Serey, \& DiFrancesco, 2015).

Cognitive flexibility is also a predictor of reading ability, as pointed out by the study by Gonçalves et al. (2017) who, using the Tower of Hanoi test (variable time of execution) and also the word reading test (TDE-II) found that cognitive flexibility is invoked for alternating between different reading routes (phonological and lexical) in the proper pronunciation of frequent, rare, and pseudowords.

Arrington, Kulesz, Francis, Fletcher, and Barnes (2014) assessed different components of attentional control, such as: response to inhibition (suppression of unnecessary stimuli before processing them), cognitive inhibition (effort to inhibit unwanted information after being perceived, or inhibitory control) and sustained attention, and reading (recognition of words and pseudowords, and comprehension), in 1,134 American students enrolled in the $6^{\text {th }}$ to $12^{\text {th }}$ grade (equivalent to the senior year of high school in Brazil), without learning difficulties. Analysis of the correlation between these assessments showed that the response to inhibition has a direct effect on the decoding assessed in word reading and that cognitive inhibition and sustained attention significantly affect reading comprehension. According to Arrington et al. (2014), the response to inhibition serves as a mechanism that represents irrelevant information, before occupying space in WM. In the reading comprehension, sustained attention ensures the focus on what is important to provide 
WM with an opportunity to manipulate information, while cognitive control (deletion) excludes or discards meanings of words or sentences that may have a dubious or inappropriate meaning in the text; that is, these two components regulate the contents manipulated in the WM during reading.

Several studies assess, as well as decoding, reading comprehension (Berninger, Abbott, Cook, \& Nagy, 2017; Lima, 2015; Locascio, Mahone, Eason, \& Cutting, 2010; Sesma et al., 2009), precisely because high-performance functions such as planning, organizing, monitoring, and self-regulating are necessary to understand and manipulate the content of the text being read. For this reason, Sesma et al. (2009) state that executive functions are greater predictors of deficits in reading comprehension than decoding. This does not exclude the importance of basic executive functions, such as working memory, which keep information in memory while extracting the meaning of the word or sentence being read (Sesma et al., 2009).

Locascio et al. (2010) also assessed different groups of students (with difficulties in reading words, specific difficulties in reading comprehension, and control without difficulties). They concluded that executive functions are necessary for basic and complex reading skills, such as reading comprehension. Children with a deficit in comprehension performed worse than children with a deficit in reading words in the planning area, even after the study had controlled the results of phonological processing. There was a distinction between groups in planning, learning, and obeying rules, and skills to establish and maintain instructions in memory. Those with word reading deficits were slower in maintaining rules in working memory. Students with specific reading comprehension difficulties made more mistakes in violating rules, organization, and inefficient planning for specific tasks. This shows that the monitoring during reading and the organization of the material are predictors of reading comprehension.

Taking this theoretical contribution into account, the question is: do students with developmental dyslexia have performance deficits in phonemic awareness activities and executive functions, when comparing their performance to that of students without dyslexia?

To answer this question, this study aims to investigate the correlations between the performance of participants in phonemic awareness, executive functions, and reading (word recognition, reading and understanding sentences and small texts), as well as possible deficits in phonemic awareness and executive functions among students with developmental dyslexia.

\section{Method}

This study complies with the ethical principles guided by the National Health Council, according to Resolution $n^{\circ}$ 466/2012, being approved by the Ethics Committee of the Universidade Federal do Paraná (UFPR, Federal University of Paraná) and authorized by the Municipal Education Department of the city of Curitiba, the institution in which it was carried out, opinion $n^{\circ} 1.669 .461$.

\section{Participants}

Twenty-eight male students participated in this study, between 9 and 11 years old, 14 with developmental dyslexia and 14 from a control group with the same age group without reading difficulties, enrolled in the $4^{\text {th }}$ and $5^{\text {th }}$ grades of Elementary School, all students from city public schools, from the same region (center-south) of the city of Curitiba. The average age of the group of dyslexics is 10.34 and of the control group is 9.89. The comparison between groups using the Mann-Whitney statistical test showed that there is no significant difference $(U=76.50 ; p<323)$ in relation to the age variable. 


\section{Instruments}

Three instruments were used to assess reading: the Teste de Desempenho Escolar (TDE, School Performance Test), isolated word reading test (Stein, 1994), the Prova de Avaliação dos Processos de Leitura (PROLEC, Assessment of reading processes) (reading test and understanding of small texts, Capellini, Oliveira, \& Cuetos, 2014), and the Teste de Leitura: Compreensão de Sentenças (TELCS, Reading Test: Understanding Sentences) (Test of reading and understanding sentences, Vilhena, Sucena, Castro, \& Pinheiro, 2016). To assess phonemic awareness, the Tarefas de Consciência Fonêmica (TCFe, Phonemic Awareness Tasks) by Godoy and Cogo-Moreira (2015) were used. To assess executive functions, some subtests of the Instrumento de Avaliação Neuropsicológica Breve (Neupsilin-inf Brief, Neuropsychological Assessment Instrument for Child) neuropsychological battery (working memory, inhibitory control and verbal fluency) (Salles et al., 2016), the Trails test (Montiel \& Seabra, 2012b), the Cancellation, and the Tower of London test were used, as described in Chart 1.

Chart 1

Instruments used in this study

\begin{tabular}{lr}
\hline Instrument & Assessed area \\
\hline TDE reading subtest (Stein, 1994). & Reading Isolated Words
\end{tabular}

PROLEC (Capellini, Oliveira \& Cuetos, Reading isolated words and reading 2014). Subtask of understanding and understanding small texts. small texts.

TELCS - Reading test: sentence Reading and understanding understanding (Vilhena et al., 2016). sentences.

TCFe, Phonemic Awareness Tasks Phonemic awareness. (Godoy \& Cogo-Moreira, 2015).

Trail Test (parts A and B) (Montiel \& Cognitive flexibility. Seabra, 2012b).

Attention Cancellation Test (Montiel \& Seabra, 2012a). attention.
Tower of London Test (Seabra et al., Planning. 2012).
Procedure

The participant should read 70 isolated words aloud. These words have an increasing degree of difficulty. There is no minimum application time. The test is interrupted when the child misses a sequence of 5 words.

The participant should read isolated words and small texts aloud. The test was interrupted if the participant was unable to read an appropriate sequence of 5 words.

The participant should read an incomplete sentence and choose, among five words, the one that best completed the sentence, to demonstrate whether he or she understood its content.

The participant should perform phonemic subtraction (CVC* and $\left.C C^{*}\right)$, phonemic inversion $\left(V C^{*}, C V^{*}, C V C^{*}\right.$ and $\left.V C V^{*}\right)$, segmentation and auditory acronyms with pseudowords. ${ }^{*} \mathrm{C}=$ consonant; $\mathrm{V}=$ vowel

In the first part (Part A), the participant should conduct a visual search and connect the numbers in the numerical sequence, and later he or she should connect the letters in the alphabetical order. In the second part (part $B$ ), the participant would need to link the items, alternating the sequence of letters and numbers (1-A, 2-B, 3-C, etc.), in a maximum time of one minute.

This test consists of three activities, in which the participant needed to mark certain symbols, according to the model presented. In the first part, only one symbol was presented, in the second, a pair of symbols that should only be marked when they appear together and, finally, the target stimulus was changed in each line of the test.

This instrument consists of a wooden base, with three pins of different sizes, and three spheres (red, blue, and green). The participant received a problem with a card, in which the spheres would be in a certain position, and they should reach that result with the least number of movements possible. The student had three chances to solve each problem. The score was assigned according to the number of attempts. The time to execute the text was recorded by the examiner. 
Instrument

Working memory - NEUPSILIN-INF

(Salles et al., 2016). Four tasks comprising the working memory assessment: repetition of digits in forward and reverse orders, span of pseudowords, and visuospatial component assessment.
Go/No Go Task - NEUPSILIN-INF (Salles et al., 2016).

\section{Assessed area}

Auditory attention, central executive, phonological, and visuospatial components of working memory.

Inhibitory control through auditory stimuli.

Verbal Fluency Task - NEUPSILIN-INF Verbal fluency. Executive functions. (Salles et al., 2016).

Procedure

In the tests of repetition of digits in forward and inverse order, the participant was asked to repeat the digits according to the orientation of the examiner. The test was interrupted in both tasks, after the participant missed three consecutive digit sequences. In the Pseudoword Span, the participant needed to repeat pseudowords in the order presented by the examiner. And, in the visuospatial working memory task, the child was asked to repeat some of the examiner's movements, however, in reverse order. For this test, a matrix with eight squares was used, to which the examiner pointed in a certain order. The child observed and then should correctly reproduce the movements.

The participant heard a sequence of numbers on a stereo, recited with a pause of one second between each number, and then had to say the word "yes" when he or she heard each number, except when he or she heard the number eight, in which the child should remain silent. Errors and omissions were computed, for a total of 60 stimuli.

The participant was asked to evoke all the words he or she could remember that started with the letter $\mathrm{M}$. The semantic task requires that the examiner think and speak as many words of a given semantic category, for example animals, as quickly as possible. The time to perform each task was one minute for each category.

Note: NEUPSILIN-INF: Brief, Neuropsychological Assessment Instrument for Child; PROLEC: Assessment of Reading Processes; TCFe: Phonemic Awareness Tasks; TDE: School Performance Test; TELCS: Reading Test: Understanding Sentences.

\section{Procedures}

Participants with developmental dyslexia were recruited at a Centro de Atendimento Educacional Especializado (Specialized Educational Service Center) in the city of Curitiba. All of them had been assessed by a multidisciplinary team, composed of a psychologist and a pedagogue from the center and a neuropediatric doctor. Their diagnosis was confirmed by the research team, with the application of instruments for assessing intelligence, reading and executive functions. For students with dyslexia, 3 or 4 individual assessment sessions were held at the Centro de Atendimento Educacional Especializado itself.

The participants in the control group were appointed by educators from the same schools where participants with dyslexia were studying. The selection criteria were sex, age, and not having a learning disability. The assessment of these participants was carried out in the schools where they studied, in 2 or 3 individual sessions. The sessions in both groups lasted from 45 to 60 minutes, varying in time and amount depending on the degree of difficulty for each participant to perform.

\section{Data analysis}

Due to the reduced number of participants in the groups, the tests applied for statistical analysis were non-parametric (Siegel \& Castellan, 1975). Initially, the raw results were subjected to descriptive analyzes; subsequently, to verify possible statistically significant differences in the performance of the groups, the Mann-Whitney test was applied, adopting a significance level of $p<0.05$; and, subsequently, to verify the correlation, the results of the groups were submitted to Spearman's correlation test, both in the IBM ${ }^{\circledR}$ SPSS $^{\circledR}$ Software, between reading performance, phonemic awareness, and EF. For better visualization, indices with significant correlation were marked in bold, that is, when $p<0.05$. 


\section{Results}

In Table 1, it is possible to observe that the groups have no significant differences in age, which confirms the possibility of comparing them. As for the assessment made in the applied instruments, it is observed that the groups differ significantly both in the reading assessments made in the TDE $(U=1.5$; $p<0.000)$ and PROLEC - General Score $(U=0.0 ; p<0.000)$, and in the reading comprehension assessments of sentences $(U=4.0 ; p<0.000)$ and short texts $(U=12.50 ; p<0.000)$, and in the phonemic awareness assessment $(U=1.00 ; p<0.000)$.

Table 1

Comparison of inter-group results, Mann-Whitney Test

\begin{tabular}{|c|c|c|c|c|c|c|}
\hline \multirow{2}{*}{ Dyslexics group X Control group by age } & \multicolumn{2}{|c|}{ Dyslexics } & \multicolumn{2}{|c|}{ Control Group } & \multirow{2}{*}{$U$} & \multirow{2}{*}{$p$} \\
\hline & Mean & Median & Mean & Median & & \\
\hline Age & 10.34 & 10.11 & 9.89 & 9.79 & 76.500 & 0.323 \\
\hline TDE - Word reading & 23.50 & 17.50 & 65.86 & 67.00 & 1.500 & $0.000^{* *}$ \\
\hline PROLEC - Frequent word reading & 10.29 & 10.00 & 19.79 & 20.00 & 8.000 & $0.000^{* *}$ \\
\hline PROLEC - Rare word reading & 7.93 & 8.00 & 18.43 & 19.00 & 0.500 & $0.000^{* *}$ \\
\hline PROLEC - Pseudoword reading & 6.79 & 8.00 & 18.14 & 19.00 & 3.000 & $0.000^{* *}$ \\
\hline PROLEC - Frequent, rare, pseudoword reading & 25.00 & 26.00 & 56.36 & 58.00 & 58.000 & $0.015^{*}$ \\
\hline TELCS - Understanding sentences & 2.50 & 0.00 & 19.79 & 19.00 & 4.000 & $0.000^{* *}$ \\
\hline PROLEC - Text comprehension & 3.36 & 0.00 & 12.00 & 12.50 & 12.500 & $0.000^{* *}$ \\
\hline PROLEC - Overall Score & 97.50 & 97.50 & 194.43 & 198.50 & 0.000 & $0.000^{* *}$ \\
\hline Phonemic awareness & 9.57 & 4.50 & 48.86 & 52.50 & 1.000 & $0.000^{* *}$ \\
\hline Trails - A & 17.14 & 19.00 & 22.36 & 24.00 & 40.000 & $0.005^{* *}$ \\
\hline Cognitive Flexibility - Trails - B & 6.14 & 6.50 & 13.64 & 14.50 & 9.500 & $0.000^{* *}$ \\
\hline Working memory - Forward digits & 17.36 & 18.00 & 22.57 & 24.00 & 34.000 & $0.003^{* *}$ \\
\hline Working memory - Reverse digits & 11.21 & 12.50 & 17.79 & 19.50 & 36.000 & $0.004^{* *}$ \\
\hline Working memory - Pseudoword span & 9.79 & 9.00 & 12.64 & 13.00 & 51.500 & $0.032^{*}$ \\
\hline Working memory - Visuospatial & 17.43 & 17.50 & 23.71 & 23.00 & 41.000 & $0.008^{* *}$ \\
\hline Working memory - Total score & 55.79 & 59.00 & 16.71 & 78.50 & 21.000 & $0.000^{* *}$ \\
\hline Planning - Tower of London & 28.50 & 28.50 & 28.43 & 29.00 & 97.000 & 0.963 \\
\hline Planning - Tower of London - Execution time (seconds) & 302.93 & 282.50 & 269.93 & 274.50 & 84.000 & 0.520 \\
\hline Orthographic verbal fluency & 3.79 & 3.00 & 6.86 & 7.00 & 36.000 & $0.004^{* *}$ \\
\hline Semantic verbal fluency & 12.43 & 12.00 & 14.36 & 13.00 & 78.000 & 0.355 \\
\hline Verbal fluency - Total score & 16.21 & 16.00 & 21.21 & 20.00 & 52.000 & $0.034^{*}$ \\
\hline Inhibitory control - Go/No Go & 50.57 & 51.50 & 54.43 & 54.00 & 50.000 & $0.026^{*}$ \\
\hline Inhibitory control - Go/No Go - Errors & 5.43 & 4.00 & 2.79 & 2.50 & 39.500 & $0.006^{* *}$ \\
\hline Inhibitory control - Go/No Go - Omissions & 3.86 & 2.50 & 2.64 & 2.00 & 77.500 & 0.339 \\
\hline Inhibitory control - Cancellation - Total score & 76.14 & 79.00 & 83.00 & 84.00 & 65.000 & 0.129 \\
\hline Inhibitory control - Cancellation - Total errors & 0.57 & 0.00 & 0.14 & 0.00 & 82.000 & 0.304 \\
\hline Inhibitory control - Cancellation - Total omissions & 31.79 & 29.00 & 25.29 & 25.50 & 68.500 & 0.175 \\
\hline
\end{tabular}

Note: ${ }^{*} p<0.05 ;{ }^{* *} p<0.01$. PROLEC: Assessment of Reading Processes; TDE: School Performance Test (reading subtask); TELCS: Reading Test: Understanding Sentences. Degree of freedom equal to 2 . For better visualization, indices with significant correlation were marked in bold, that is, when $p<0.05$.

The groups also differed significantly in cognitive flexibility $(U=9.50 ; p<0.000)$, working memory - total score $(U=21.00 ; p<0.000)$, Orthographic Verbal Fluency $(\mathrm{OVF})(U=36.00 ; p<0.004)$, and total $(U=52.00 ; p<0.034)$, and inhibitory control measured by Go/No Go $(U=50.00 ; p<0.026)$. There was no significant difference between the groups in the planning assessment (Tower of London), Semantic Verbal Fluency, and Cancellation Test. 
As shown in Table 2, most EF correlated significantly and moderately with the word reading, reading comprehension of sentences and short texts, and phonemic awareness assessments. The word reading assessments made in the TDE correlated significantly and moderately with cognitive flexibility, in parts $\mathrm{A}(r h o=0.545 ; p<0.003)$ and $\mathrm{B}(r h o=0.672 ; p<0.000)$ of the test; with working memory in its four components, and total score $(r h o=0.746 ; p<0.000)$; with orthographic verbal fluency ( $r h o=0.563 ; p<0.002$ ) and total verbal fluency score $(r h o=0.540 ; p<0.003)$; and also with the inhibitory control assessed with the Go/No Go instrument $(r h o=0.556 ; p<0.002)$. The TDE showed no correlation with the planning, measured with the Tower of London ( $r h o=0.081 ; p<0.682$ ) and with the Cancellation test used to also assess the inhibitory control (rho $=0.359 ; p<0.061)$.

Table 2

Spearman correlation of the participants' performance in reading tests, phonemic awareness, and executive functions

\begin{tabular}{|c|c|c|c|c|c|c|c|c|c|c|}
\hline \multirow[t]{2}{*}{ Variables } & \multicolumn{2}{|c|}{ Age } & \multicolumn{2}{|c|}{ TDE } & \multicolumn{2}{|c|}{ TELCS } & \multicolumn{2}{|c|}{$\begin{array}{c}\text { PROLEC - } \\
\text { Comprehension }\end{array}$} & \multicolumn{2}{|c|}{$\begin{array}{l}\text { Phonemic } \\
\text { Awareness }\end{array}$} \\
\hline & rho & $p$ & rho & $p$ & rho & $p$ & rho & $p$ & rho & $p$ \\
\hline Age & 1.000 & & & & & & & & & \\
\hline TDE & -0.105 & 0.596 & 1.000 & & & & & & & \\
\hline TELCS & -0.032 & 0.870 & $0.917^{* *}$ & 0.000 & 1.000 & & & & & \\
\hline PROLEC - Understanding & -0.119 & 0.547 & $0.840^{* *}$ & 0.000 & $0.866^{* *}$ & 0.000 & 1.000 & & & \\
\hline Phonemic Awareness & -0.151 & 0.442 & $0.905^{* *}$ & 0.000 & $0.886^{* *}$ & 0.000 & $0.835^{* *}$ & 0.000 & 1.000 & \\
\hline$C F-$ Trails - A & -0.267 & 0.170 & $0.545^{* *}$ & 0.003 & $0.492^{* *}$ & 0.008 & 0.362 & 0.058 & $0.554^{* *}$ & 0.002 \\
\hline CF -Trails - B & -0.091 & 0.645 & $0.672^{* *}$ & 0.000 & $0.754^{* *}$ & 0.000 & $0.658^{* *}$ & 0.000 & $0.772^{* *}$ & 0.000 \\
\hline WM - Direct digits & -0.259 & 0.183 & $0.643^{* *}$ & 0.000 & $0.666^{* *}$ & 0.000 & $0.624^{* *}$ & 0.000 & $0.608^{* *}$ & 0.001 \\
\hline WM - Reverse digits & -0.357 & 0.062 & $0.631^{* *}$ & 0.000 & $0.637^{* *}$ & 0.000 & $0.733^{* *}$ & 0.000 & $0.715^{* *}$ & 0.000 \\
\hline WM - Pseudoword span & -0.188 & 0.337 & $0.478^{*}$ & 0.010 & $0.407^{*}$ & 0.032 & $0.395^{*}$ & 0.038 & $0.384^{*}$ & 0.044 \\
\hline WM - Visuospatial & 0.126 & 0.523 & $0.504^{* *}$ & 0.006 & $0.501^{* *}$ & 0.007 & $0.479^{* *}$ & 0.010 & $0.436^{*}$ & 0.020 \\
\hline WM - Total score & -0.209 & 0.285 & $0.746^{* *}$ & 0.000 & $0.742^{* *}$ & 0.000 & $0.746^{* *}$ & 0.000 & $0.744^{* *}$ & 0.000 \\
\hline Planning - Tower of London & 0.336 & 0.081 & 0.081 & 0.682 & 0.078 & 0.692 & 0.133 & 0.499 & 0.023 & 0.906 \\
\hline $\begin{array}{l}\text { Planning - Tower of London - } \\
\text { Execution time (seconds) }\end{array}$ & 0.014 & 0.945 & -0.145 & 0.462 & -0.157 & 0.425 & -0.221 & 0.259 & 0.036 & 0.858 \\
\hline Spelling verbal fluency & -0.008 & 0.967 & $0.563^{* *}$ & 0.002 & $0.660^{* *}$ & 0.000 & $0.505^{* *}$ & 0.006 & $0.607^{* *}$ & 0.001 \\
\hline Semantic verbal fluency & -0.090 & 0.648 & 0.331 & 0.086 & 0.362 & 0.058 & 0.225 & 0.251 & 0.316 & 0.102 \\
\hline Verbal fluency - Total score & -0.061 & 0.758 & $0.540^{* *}$ & 0.003 & $0.588^{* *}$ & 0.001 & $0.399^{*}$ & 0.035 & $0.543^{* *}$ & 0.003 \\
\hline IC - Go/No Go & -0.009 & 0.964 & $0.556^{* *}$ & 0.002 & $0.511^{* *}$ & 0.005 & $0.550^{* *}$ & 0.002 & $0.396^{*}$ & 0.037 \\
\hline IC - Go/No Go - Errors & 0.109 & 0.582 & $-0.572^{* *}$ & 0.001 & $-0.561^{* *}$ & 0.002 & $-0.400^{*}$ & 0.035 & $-0.482^{* *}$ & 0.009 \\
\hline IC - Go/No Go - Omissions & -0.109 & 0.582 & -0.273 & 0.159 & -0.268 & 0.167 & $-0.379^{*}$ & 0.047 & -0.148 & 0.451 \\
\hline IC - Cancellation - Total score & 0.088 & 0.657 & 0.359 & 0.061 & $.0377^{*}$ & 0.048 & 0.305 & 0.115 & $0.421^{*}$ & 0.026 \\
\hline IC - Cancellation - Total errors & $0.504^{* *}$ & 0.006 & -0.193 & 0.324 & -0.060 & 0.760 & -0.079 & 0.689 & -0.343 & 0.074 \\
\hline IC - Cancellation - Total omissions & -0.113 & 0.566 & -0.322 & 0.094 & -0.361 & 0.059 & -0.278 & 0.152 & $-0.412^{*}$ & 0.029 \\
\hline
\end{tabular}

Note: ${ }^{*} p<0.05 ;{ }^{* *} p<0.01$. CF: Cognitive Flexibility; WM: Working Memory; IC: Inhibitory Control; PROLEC: Assessment of Reading Processes; TDE: School Performance Test (reading subtask); TELCS: Reading Test: Understanding Sentences. For better visualization, indices with significant correlation were marked in bold, that is, when $p<0.05$.

The reading comprehension of sentences assessed with the TELCS showed to be moderately and significantly correlated with the performance of the Trail test (cognitive flexibility) A ( $r h o=0.492 ; p<0.008$ ) and $\mathrm{B}(r h o=0.754 ; p<0.000)$; with the four components of working memory and general score $(r h o=0.742$; $p<0.000)$; with orthographic verbal fluency $(r h o=0,660 ; p<0.000)$ and general score $(r h o=0.588$; $p<0.001)$; with the inhibitory control in the Go/No Go test (rho $=0.511 ; p<0.005)$, having a negative 8 correlation with the amount of errors made in this instrument $(r h o=-0.561 ; p<0.002)$, and correlation with 
the measured inhibitory control assessment with the Cancellation test ( $r h o=0.377 ; p<0.048$ ). The only instrument that showed no correlation with sentence comprehension and with any other reading instrument was the Tower of London test.

In the reading assessment of small texts made with the PROLEC, it is possible to observe the very significant correlation between the score of understanding of small texts with the performance in part B of the Trails test $(r h o=0.658 ; p<0.000)$, with the four components of the working memory and general score ( $r h o=0.746 ; p<0.000)$; with orthographic verbal fluency ( $r h o=0.505 ; p<0.006)$ and general score $(r h o=0.399 ; p<0.035)$; with the inhibitory control in the Go/No Go test ( $r h o=0.550 ; p<0.002)$, having a negative correlation with the number of errors ( $r h o=-0.400 ; p<0.035)$ and omissions ( $r h o=-0.379 ; p<0.047$ ) committed in that instrument. It showed no correlation with the Cancellation and the Tower of London.

Phonemic awareness was shown to correlate moderately and significantly with all reading instruments and with the same executive functions that showed correlation with other reading instruments. The correlation with cognitive flexibility of the Trails test was $(r h o=0.554 ; p<0.002)$ in part $A$ and $(r h o=0.772 ; p<0.000)$ in part $\mathrm{B}$. The correlation with working memory was ( $r h o=0.744 ; p<0.000)$ in the general score, and in the inhibitory control Go/No Go there was a positive correlation in the performance score ( $r h o=0.396 ; p<0.037$ ) and a negative correlation in the mistakes made ( $r h o=0.482 ; p<0.009$ ). The Cancellation test, also used to assess inhibitory control, showed a correlation with phonemic awareness (rho $=0.421 ; p<0.026$ ) and with the omissions committed in this instrument $(r h o=0.412 ; p<0.029)$.

\section{Discussion}

The results of the Phonemic Awareness and reading comprehension assessments of sentences and short texts were found to be correlated with each other. In other words, the data obtained in this investigation showed that when the performance of both dyslexics and skilled readers in a task involving phonemic awareness is lowered, their performance in a reading task (word recognition), understanding sentences or texts, is also compromised, and vice versa. These results corroborate those of Godoy (2016), who found a strong correlation between phonological awareness and the ability to spell and read in skilled readers.

Analyzing the data obtained in this study, Spearman's correlation test showed that the phonemic awareness score correlated with working memory assessments (total, forward, and inverse digits, and span of pseudowords), cognitive flexibility (Trails A and B), orthographic verbal fluency, and inhibitory control. These results are in line with what was verified by Cardoso et al. (2013), who found, among the participants in their study, a correlation between the results of the working memory assessment and the results in the phoneme subtests of the CONFIAS test. On the other hand, the Spearman test also showed that the phonemic awareness score had a negative correlation with the number of errors made in the Go/No Go test and with the number of omissions in the Cancellation, so that the better the performance in the phonemic awareness assessment, the fewer errors and omissions involving inhibitory control were made.

The Cancellation test, according to Godoy (2012, p. 42), is indicated to assess selective attention, "a cognitive mechanism that allows the individual to process relevant information, thoughts, or actions of a task, ignoring distracting or irrelevant stimuli". The Go/No Go test also assesses the ability to ignore distracting stimuli but uses auditory stimuli for the assessment. In both assessments, the participant needs to respond quickly, as his score depends on the speed with which he performs the task. In this perspective, the non-correlation of the phonemic awareness task and reading assessments with the Cancellation test may be related to the fact that the phonemic awareness task did not impose a specific time for the response, relaxing the participant, enabling him or her to show his or her best performance without the stress of having to respond in a short period of time. Another difference between these tasks is that, in phonemic awareness, the stimulus involves 
processing the sound of the syllables; in the Cancellation test, symbols are used. In other words, different stimuli require different processing. A final difference between the tasks that assess inhibitory control using the Cancellation test and phonemic awareness is the type of cognitive performance of each test. In tests that assess inhibitory control, there is a greater demand for the participant to pay attention to perform what is requested; in the task of phonemic awareness, in addition to the attention to capture the stimulus, the participant needs to mentally manipulate the information. This fact has already been demonstrated in the correlation of this task with the general performance of working memory, not only in this study, but also in the study by de Cardoso et al. (2013) and Moura et al. (2015a).

When analyzing each working memory task separately, it is observed that, in the first one, in which the participants were asked to repeat a sequence of digits in the same order (forward digits), there was a significant correlation with all the reading and phonemic awareness assessments. It should be noted that this task also shows their auditory attention performance, which allowed the researchers of this study to state that, when auditory attention and storage capacity are deficient, the ability to perform phonemic awareness tasks and, consequently, reading may also be deficient.

Phonemic awareness was also correlated with orthographic OVF, but not with Semantic Verbal Fluency (SVF). In the VF task, the participants needed to access, in their mental lexicon, words that correspond to the requested letter (OVF - letter $\mathrm{m}$ ) and the animal category (SVF) in the mental lexicon. Access to the semantic category is related to an individual's vocabulary and repertoire of experiences, while OVF is related to knowledge of the language and familiarization with the writing of words. When an individual does not make the grapheme-phoneme conversion, he or she consequently finds it difficult to relate the initial sound of the words to the letter. The correlation between phonemic awareness and OVF confirms this hypothesis, as well as the non-correlation with SVF, which does not depend on phonemic awareness for its execution.

The TDE assessment showed a positive correlation with working memory (all measures), cognitive flexibility, orthographic verbal fluency, and inhibitory control assessed with the Go/No Go test. These results are in agreement with those of the study of Gonçalves et al. (2017) who found an association between performance on the word reading test (TDE-II part A; $1^{\text {st }}$ to $4^{\text {th }}$ grade; $n=121$ ) and the OVF (mental lexicon), phonological working memory (Arithmetic - WISC IV), inhibitory control (errors in OVF), and executive attention (errors in the Go/No Go and Cancellation tests) assessments.

Berninger et al. $(2008,2017)$ and Reiter et al. (2005) studied working memory deficits in dyslexics and found a strong correlation between this executive function and reading, concluding that the problems in decoding, spelling, and reading fluency are related, in some way, to the deterioration of working memory. During reading, working memory conjugates and maintains visual and phonological elements in the mind, while connecting information to the mental lexicon, seeking coherence for the proper understanding. If this consistency is not found by the reader, the working memory is overloaded and demands more time for reading, which often becomes exhausting, as in the case of dyslexics who have not yet mastered decoding and fail to read simple words, or when they do dominate it and fail to read unknown words and pseudowords.

Other assessment results that showed a correlation in the present research were reading words and understanding sentences and texts with OVF. Semantic verbal fluency was not correlated with any reading measure. Several studies (Lima, Anzoni, \& Ciasca, 2013; Moura, Simões, \& Pereira, 2015b; Reiter et al., 2005) show the difference in performance between dyslexics and members of the control group in verbal fluency tasks, however, few present the correlation of this performance with tasks of reading words, with reading comprehension being the most usual correlation.

In the comparison made by Gonçalves et al. (2017), a correlation was identified between the amount of words evoked in both the orthographic and semantic verbal fluency task, when students from the $1^{\text {st }}$ to 
the $4^{\text {th }}$ grade of Elementary School were assessed; in the assessment of students from the $5^{\text {th }}$ to the $9^{\text {th }}$ grade, only correlation with orthographic verbal fluency was identified. When the participants are younger, there is a greater cognitive demand for the retrieval of information in the mental lexicon, which, over time, becomes more natural and spontaneous due to the fact that the individual feels more competent academically or, also, due to the fact that the task of reading and evoking semantic categories of words has become easier (Dias \& Seabra, 2013). Semantic verbal fluency requires fewer executive resources than orthographic verbal fluency and reading, so it has less correlation (Smith-Spark et al., 2017).

With regard to inhibitory control and word reading, there is empirical evidence of the importance of this executive component for learning to read, especially in dyslexics, however, it is observed that the type of instrument used in the assessments generates discussions, since different studies using different instruments to assess the same component, which leaves doubts regarding the best instrument to be used (Abreu et al., 2014; Bovo et al., 2016; Gonçalves et al., 2017; Lima et al., 2013; Medina et al., 2017; Reiter et al., 2005). In the present research, the Go/No Go test (in the inhibitory control) was used, as it is one of the most used tests in studies with dyslexics, and the performance of the participants in it showed a correlation with the performance in reading isolated words measured with the TDE, and in reading and understanding sentences and texts.

There was also a negative correlation of these reading assessments, with the amount of errors made in the Go/No Go test; that is, the more words read correctly, the fewer errors of inhibitory control. With the use of the Cancellation test, which indicates inhibitory control and, mainly, selective attention, no correlation was found with the reading tasks (words and texts), only with the reading of sentences.

Using a different version of the Go/No Go and other instruments, Abreu et al. (2014) assessed 106 children - half of them were good readers and the other half were children with reading difficulties, according to the teachers' assessment -, in executive functions (cognitive flexibility, working memory, inference suppression, selective attention and inhibitory response). The authors correlated performance in executive functions with performance in different academic areas. Reading (recognition) showed a correlation with selective attention, inference suppression and inhibitory response, while reading comprehension correlated with inference suppression and selective attention. Unlike Abreu et al. (2014), in the present study, the selective attention assessed in the Cancellation test showed no correlation with reading. However, the results of these authors corroborate those of this study, regarding the assessment performed with the Go/No Go test (inhibitory response and inference suppression / cognitive inhibition).

For Arrington et al. (2014), the response to inhibition may be related to the monitoring done when the reader needs to control him or herself to properly read words that have similar spelling to other words, controlling not to read them in the same way as the similar word. This difficulty is greater in countries where the language is less clear and has letters that express different sounds, according to the grammatical rule.

Based on the study by Abreu et al. (2014) and Arrington et al. (2014), it can be hypothesized that, in the present study, the Go/No Go test acted in the assessment of the response to inhibition and sustained attention; the Cancellation test acted in the assessment of the stimulus selection (selective attention) and cognitive inhibition. Another point that may justify the non-correlation of the Cancellation test with the reading of words and understanding of texts may be the fact that symbols (and not letters) are used as stimuli. This suggests that the Cancellation test is not efficient for assessing people who have a reading disorder exclusively. It may be useful to point out comorbidities, such as dyslexia with attention deficit hyperactivity disorder (Montiel et al., 2014). A final point on this subject is to consider that the Cancellation test (Montiel \& Seabra, 2012a) has three different steps and each uses a different inhibition principle, as in the third phase, when the examiner needs, in addition to selecting the stimulus, to switch between stimuli and inhibit distractors. Then, it is considered that, in a second step, the correlation of each subtest of all instruments used in the 
research could be processed and group the components that meet the same principles of cognitive action, creating executive factors to then correlate them with performance in reading, as was done in the studies by Abreu (2014); Dias and Seabra (2013), and Locascio et al. (2010).

Continuing the correlational analysis of the present study, it is observed that there was no correlation between the phonemic awareness, word reading, and reading comprehension assessments with the planning assessment made using the Tower of London test. This finding confirms the study by Bovo et al. (2016), which has been previously mentioned, who also did not identify such a correlation when assessing students with learning difficulties.

Several studies point to a deficit in planning for dyslexics, but not using the Tower of London teste, but using, for example, the Wisconsin Card Sorting Test. This is the case with the study by Fadaei et al. (2017), who, using this instrument, identified a correlation between planning and reading difficulties in children with learning disorders, not only in recognition, but also in understanding. According to Fadaei et al. (2017), planning is an executive function more related to reading comprehension. Understanding depends on high executive functioning skills, such as reasoning, critical analysis, planning, and organization, unlike decoding, which requires more basic executive functions, such as working memory and cognitive flexibility (Sesma et al., 2009).

With regard to reading comprehension and executive functions, some aspects have been previously pointed out; in summary, the performance in the TELCS, which assesses reading comprehension of sentences, and in the PROLEC, which assesses understanding of short texts, showed a correlation with cognitive flexibility, working memory, orthographic verbal fluency, and inhibitory control measured with the Go/No Go test. The number of errors and omissions made in the Go/No Go test has a negative correlation with the reading comprehension of sentences, that is, those who have better reading skills have less difficulty in distraction.

It is a consensus among scholars that executive functions are important for reading comprehension (Abreu et al., 2014; Bovo et al., 2016; Gnaedinger, Hund, \& Hesson-McInnis, 2016; Fadaei et al., 2017; Locascio et al., 2010; Sesma et al., 2009). Thus, once the recognition and decoding of frequent words is automated, the executive functions act so that this process occurs smoothly, collaborating with the understanding of what is being read, that is, of comprehension. Although some scholars point out that EF are more predictive of reading comprehension than decoding (Sesma et al., 2009), due to the role that high EF (such as planning and monitoring) have in reading comprehension (Locascio et al., 2010; Sesma et al ., 2009), the basic EF, such as: working memory (Abreu et al., 2014; Bovo et al., 2016; Sesma et al., 2009), cognitive flexibility (Abreu et al., 2014; Gnaedinger et al., 2016), inhibitory control (Arrington et al., 2014; Bovo et al., 2016), and verbal fluency (Bovo et al., 2016; Smith-Spark et al., 2017), are also shown to be related to a deficit in reading comprehension.

The Cancellation test was not efficient to assess inhibitory control, but indeed for selective attention, just as the Tower of London test needs to be reconsidered as a measure to assess planning, when it is intended to make correlations, and especially when the study involves dyslexics.

It is important to note that most of the studies referenced here and with which the data from this research were compared to are of foreign origin, many of them coming from English-speaking countries, which is a less transparent language with regard to the letter-sound relationship than Brazilian Portuguese.

\section{Conclusion}

The result of the correlation analyzes carried out showed similarities and differences with those found in other studies, but, in general, they point to the existence of significant correlations between the 
performance in the phonemic awareness and reading tasks (recognition and comprehension) and the tasks that assessed cognitive functioning involving the following executive functions: cognitive flexibility, working memory, inhibitory control, and orthographic verbal fluency. These results make it possible to hypothesize that an intervention planned for the development of phonemic awareness and executive functions may have an effect in improving the reading performance of dyslexics.

The establishment of correlations between these variables - phonemic awareness, reading performance, and EF -, is already an advance in terms of research results involving Brazilian participants, although it is recognized that an entire research agenda must be established to verify possible cause and relationship effects between these variables, including in students of different chronological ages.

In general, the results confirm the existence of significant relationships between EF and reading performance. However, to verify how EF develop, longitudinal studies that combine correlational techniques, are necessary. These studies should explore whether there is a causal relationship between the improvement in EF and the improvement in reading capacity, if, on the contrary, reading makes it possible to develop EF, or even if there is a bidirectional relationship between them. In addition, future studies should investigate the effect that interventions for the development of EF can have on reading performance.

\section{Acknowledgments}

The authors would like to thank the Municipal Education Department of Curitiba, the schools and their educators for their attention and, mainly and especially, to the students for their valuable collaboration.

\section{Contributors}

G. B. K. MEDINA contributed to the conception and design of the study, analysis and interpretation of data, corrections, and revision of the final version. S. R. K. GUIMARÃES contributed to the conception, guidance for preparation, corrections, and revision of the final version.

\section{References}

Abreu, E. P. M. J., Abreu, N., Nikaedo, C. C., Puglisi, M. L., Tourinho, C. J., Miranda, M. C., ... Martin, R. (2014). Executive functioning and reading achievement in school: a study of Brazilian children assessed by their teachers as "poor readers". Frontier of Psychology, 5(550), 1-14. https://doi.org/10.3389/fpsyg.2014.00550

American Psychiatric Association. (2014). Manual diagnóstico e estatístico de transtornos mentais: DSM-5 (5a ed.). Porto Alegre: Artmed.

Arrington, C. N., Kulesz, P. A., Francis, D. J., Fletcher, J. M., \& Barnes, M. A. (2014). The contribution of attentional control and working memory to reading comprehension and decoding. Scientific Studies of Reading, 18(5), 325-346. https:// doi.org/10.1080/10888438.2014.902461

Berninger, V. W., Raskind, W., Richards, T., Abbott, R., \& Stock, P. (2008). A multidisciplinary approach to understanding developmental dyslexia within working-memory architecture: genotypes, phenotypes, brain, and instruction. Developmental Neuropsychology, 33(6), 707-744. https://doi.org/10.1080/87565640802418662

Berninger, V., Abbott, R., Cook, C. R., \& Nagy, W. (2017). Relationships of attention and executive functions to oral language, reading, and writing skills and systems in middle childhood and early adolescence. Journal of Learning Disabilities, 50(4), 434-449. https://doi.org/10.1177/0022219415617167

Bovo, E. B. P., Lima, R. F. D., Silva, F. C. P. D., \& Ciasca, S. M. (2016). Relações entre as funções executivas, fluência e compreensão leitora em escolares com dificuldades de aprendizagem. Revista Psicopedagogia, 33(102), 272-282.

Capellini, S. A., Oliveira, A., \& Cuetos, F. (2014). PROLEC - Provas de avaliação dos processos de leitura. São Paulo: Casa do Psicólogo. 
Cardoso, A. M. D. S., Silva, M. M. D., \& Pereira, M. M. D. B. (2013). Consciência fonológica e a memória de trabalho de crianças com e sem dificuldades na alfabetização. Codas, 25(2), 110-114.

Corso, H. V., Sperb, T. M., Jou, G. I., \& Salles, J. F. (2013). Metacognição e funções executivas: relações entre os conceitos e implicações para a aprendizagem. Psicologia: Teoria e Pesquisa, 29(1), 21-29.

Cypel, S. (2016). Funções executivas: seu processo de estruturação e a participação no processo de aprendizagem. In N. T. Rotta, L. Ohlweiler, \& R. S. Riesgo (Orgs.), Transtornos da aprendizagem: abordagem neurobiológica e multidisciplinar (2a ed., pp. 392-406). Porto Alegre: Artmed.

Diamond, A. (2013). Executive functions. Annual Review of Psychology, 64, 135-168. https://doi.org/10.1146/annurevpsych-113011-143750

Diamond, A. (2016). Why improving and assessing executive functions early in life is critical. In J. A. Griffin, P. McCardle, \& L. S. Freund (Orgs.), Executive function in preschool-age children: integrating measurement, neurodevelopment, and translational research (pp. 11-43). Washington: APA.

Dias, N. M., \& Seabra, A. G. (2013). PIAFEX: Programa de intervenção e autorregulação e funções executivas. São Paulo: Memnon.

Fadaei, E., Tavakoli, M., Tahmasebi, A., Narimani, M., Shiri, V., \& Shiri, E. (2017). The relationship between executive functions with reading difficulties in children with specific learning disorder. Archives of Neuroscience, 4(4). https:// doi.org/10.5812/archneurosci. 13989

Fostick, L., \& Revah, H. (2018). Dyslexia as a multi-deficit disorder: working memory and auditory temporal processing. Acta Psychologica, 183, 19-28. https://doi.org/10.1016/j.actpsy.2017.12.010

Gnaedinger, E. K., Hund, A. M., \& Hesson-Mclnnis, M. S. (2016). Reading-specific flexibility moderates the relation between reading strategy use and reading comprehension during the elementary years. Mind, Brain, and Education, 10(4), 233-246. https://doi.org/10.1111/mbe.12125

Godoy, S. (2012). Evidências de validade do teste de atenção por cancelamento. In A. G. Seabra \& N. M. Dias (Orgs.), Avaliação neuropsicológica cognitiva: atenção e funções executivas (pp. 42-49). São Paulo: Memnon.

Godoy, D. M. A. (2016). Aprender a escrever: contribuição das habilidades de consciência fonêmica, nomeação seriada rápida e memória de trabalho. Revista Ibero-Americana de Estudos em Educação, 11(4), 2558-2575.

Godoy, D. M. A., \& Cogo-Moreira, H. (2015). Evidences of factorial structure and precision of phonemic awareness tasks (TCFe). Paidéia, 25(62), 363-372. http://dx.doi.org/10.1590/1982-43272562201510

Gonçalves, H. A., Viapiana, V. F., Sartori, M. S., Giacomoni, C. H, Stein, L. M., \& Fonseca, R. P. (2017). Funções executivas predizem o processamento de habilidades básicas de leitura, escrita e matemática? Revista Neuropsicologia Latinoamericana, 9(3), 42-54. http://dx.doi.org/10.5579/rnl.2016.0393

Gough, P. B., \& Larson, K. C. (1995). A estrutura da consciência fonológica. In C. Cardoso-Martins (Org.), Consciência Fonológica e Alfabetização (pp. 15-35). Petrópolis: Vozes.

Horowitz-Kraus, T., Toro-Serey, C., \& DiFrancesco, M. (2015). Increased resting-state functional connectivity in the cinguloopercular cognitive-control network after intervention in children with reading difficulties. Plos One, $10(7)$, e0133762. https://doi.org/10.1371/journal.pone.0133762

Lezak, M. D. (1982). The problem of assessing executive functions. International Journal of Psychology, 17(2-3), 281-297. http://dx.doi.org/10.1080/00207598208247445

Lima, R. F. (2015). Programa de reabilitação neuropsicológica em funções executivas para estudantes com dislexia do desenvolvimento: elaboração e eficácia (Tese de doutorado não-publicada). Universidade de Campinas, Campinas.

Lima, R. F., Azoni, C. A. S., \& Ciasca, S. M. (2013). Atenção e funções executivas em crianças com dislexia do desenvolvimento. Revista Psicologia em Pesquisa, 7(2), 208-219. http://dx.doi.org/10.5327/Z1982-1247201300020009

Locascio, G., Mahone, E. M., Eason, S. H., \& Cutting, L. E. (2010). Executive dysfunction among children with reading comprehension deficits. Journal of Learning Disabilities, 43(5), 441-454. http://dx.doi.org/10.1177/0022219409355476

Medina, G. B. K., \& Guimarães, S. R. K. (2019). Leitura de estudantes com dislexia do desenvolvimento: impactos de uma intervenção com método fônico associado à estimulação de funções executivas. Revista Brasileira de Educação Especial, 25(1), 155-174. http://dx.doi.org/10.1590/S1413-65382519000100010

Medina, G. B. K., Minetto, M. F. J., \& Guimarães, S. R. K. (2017). Funções executivas na dislexia do desenvolvimento: revendo evidências de pesquisas. Revista Brasileira de Educação Especial, 23(3), 439-454. https://dx.doi.org/10.1590/ s1413-65382317000300009

Montiel, J. M., Bartholomeu, D., Armond, G. D., Jacini, W. F. S., Bueno, C. H., Lima, F. F., \& Cecato, J. F. (2014). Associações entre medidas de funções executivas e TDAH em crianças em idade escolar. Neuropsicologia Latinoamericana, 6(1), 13-21. https://doi.org/10.5579/rnl.2013.0158 
Montiel, J. M., \& Seabra, A. G. (2012a). Teste de atenção por cancelamento. In A. G. Seabra \& N. M. Dias (Orgs.), Avaliação neuropsicológica cognitiva: atenção e funções executivas (pp. 57-66). São Paulo: Memnon.

Montiel, J. M., \& Seabra, A. G. (2012b). Teste de trilhas: partes A e B. In A. G. Seabra \& N. M. Dias (Orgs.), Avaliação neuropsicológica cognitiva: atenção e funções executivas (pp. 79-85). São Paulo: Memnon.

Moura, O., Moreno, J., Pereira, M., \& Simões, M. R. (2015a). Developmental dyslexia and phonological processing in European Portuguese orthography. Dyslexia, 21(1), 60-79. https://doi.org/10.1002/dys.1489

Moura, O., Simões, M. R., \& Pereira, M. (2015b). Executive functioning in children with developmental dyslexia. The Clinical Neuropsychologist, 28(Suppl 1), 20-41. https://doi.org/10.1080/13854046.2014.964326

Moura, O., Simões, M. R., \& Pereira, M. (2013). Fluência verbal semântica e fonêmica em crianças: funções cognitivas e análise temporal. Avaliação Psicológica, 12(2), 167-177.

Reiter, A., Tucha, O., \& Lange, K. W. (2005). Executive functions in children with dyslexia. Dyslexia, 11(2), 116-131. https://doi.org/10.1002/dys.289

Salles, J. F., Fonseca, R. P., Parente, M. A., Cruz-Rodrigues, C., Mello, C. B., Barbosa, T., \& Miranda, M. C. (2016). NEUPSILIN-INF: instrumento de avaliação neuropsicológica breve para crianças. São Paulo: Vetor.

Seabra, A. G., Dias, N. M., Barberian, A. A., Assef, E. C. F., \& Cozza, H. F. P. (2012). Teste da Torre de Londres. In A. G. Seabra \& N. M. Dias (Orgs.), Avaliação neuropsicológica cognitiva: atenção e funções executivas (pp. 79-85). São Paulo: Memnon.

Seabra, A. G., Laros, J. A., Macedo, E. C., \& Abreu, N. (2014) Inteligência e funções executivas: avanços e desafios para a avaliação neuropsicológica. São Paulo: Memnon.

Sesma, H. W., Mahone, E. M., Levine, T., Eason, S. H., \& Cutting, L. E. (2009). The contribution of executive skills to reading comprehension. Child Neuropsychology, 15(3), 232-246. https://doi.org/10.1080/09297040802220029

Siegel, S., \& Castellan, N. J., Jr. (1975). Estatística não-paramétrica para ciências do comportamento. Artmed Editora.

Smith-Spark, J. H., Henry, L. A., Messer, D. J., \& Zięcik, A. P. (2017). Verbal and non-verbal fluency in adults with developmental dyslexia: phonological processing or executive control problems? Dyslexia, 23(3), 234-250. https:// doi.org/10.1002/dys.1558

Smith-Spark, J. H., \& Fisk, J. E. (2007). Working memory functioning in developmental dyslexia. Memory, 15(1), 34-56. https://doi.org/10.1080/09658210601043384

Snowling, M. J. (2004). Dislexia (2a ed.). Santos: Livraria Santos Editora.

Snowling, M. J., \& Hulme, C. (2013). A ciência da leitura. Porto Alegre: Penso.

Stein, L. M. (1994). TDE - Teste de Desempenho Escolar: manual para aplicação e interpretação. São Paulo: Casa do Psicólogo.

Vellutino, F. R., \& Fletcher, J. M. (2013). Dislexia do desenvolvimento. In M. J. Snowling \& C. Hulme (Orgs.), A ciência da leitura (pp. 380-396). Porto Alegre: Penso.

Vilhena, D. A., Sucena, A., Castro, S. L., \& Pinheiro, A. M. V. (2016). Reading test-sentence comprehension: an adapted version of Lobrot's lecture 3 test for brazilian portuguese. Dyslexia, 22(1), 47-63. https://doi.org/10.1002/dys.1521

Received: February, 5, 2019

Final version: September 1, 2020

Approved: October 5, 2020 